\title{
Hybrid ANFIS-Rao algorithm for surface roughness modelling and optimization in electrical discharge machining
}

\author{
Agarwal, N. ${ }^{a,}{ }^{,}$, Shrivastava, N. ${ }^{a}$, Pradhan, M.K. ${ }^{b}$ \\ ${ }^{a}$ Department of Mechanical Engineering, UIT, Rajiv Gandhi Proudyogiki Vishwavidyalaya, Bhopal, India \\ ${ }^{\mathrm{b}}$ Department of Mechanical Engineering, Maulana Azad National Institute of Technology, Bhopal, India
}

\begin{abstract}
A B S T R A C T
Advanced modeling and optimization techniques are imperative today to deal with complex machining processes like electric discharge machining (EDM). In the present research, Titanium alloy has been machined by considering different electrical input parameters to evaluate one of the important surface integrity (SI) parameter that is surface roughness $R a$. Firstly, the response surface methodology (RSM) has been adopted for experimental design and for generating training data set. The artificial neural network (ANN) model has been developed and optimized for $R a$ with the same training data set. Finally, an adaptive neuro-fuzzy inference system (ANFIS) model has been developed for $R a$. Optimization of the developed ANFIS model has been done by applying the latest optimization techniques Rao algorithm and the Jaya algorithm. Different statistical parameters such as the mean square error (MSE), the mean absolute error (MAE), the root mean square error (RMSE), the mean bias error (MBE) and the mean absolute percentage error (MAPE) elucidate that the ANFIS model is better than the ANN model. Both the optimization algorithms results in considerable improvement in the SI of the machined surface. Comparing the Rao algorithm and Jaya algorithm for optimization, it has been found that the Rao algorithm performs better than the Jaya algorithm.
\end{abstract}

\author{
ARTICLE INFO \\ Keywords: \\ Electrical-discharge machining \\ (EDM); \\ Titanium alloy; \\ Surface roughness; \\ Modelling; \\ Optimization; \\ Artificial neural networks (ANN); \\ Adaptive neuro fuzzy inference \\ system (ANFIS); \\ Rao algorithm; \\ Jaya algorithm \\ *Corresponding author: \\ neeraj.bhopal@gmail.com \\ (Agarwal, N.) \\ Article history: \\ Received 27 October 2020 \\ Revised 14 March 2021 \\ Accepted 15 May 2021
}

\section{References}

[1] Jain, V.K. (2009). Advanced machining processes, Allied publishers, Mumbai, India.

[2] Klink, A. (2019). Electric discharge machining, In: Chatti, S., Laperrière, L., Reinhart, G., Tolio, T. (eds.), CIRP Encyclopedia of Production Engineering, Springer, Berlin, Germany, doi: 10.1007/978-3-662-53120-4_6478.

[3] Abbas, N.M., Solomon, D.G., Bahari, M.F. (2007). A review on current research trends in electrical discharge machining (EDM), International Journal of Machine Tools and Manufacture, Vol. 47, No. 7-8, 1214-1228, doi: 10.1016/j.ijmachtools.2006.08.026.

[4] Ho, K.H., Newman, S.T. (2003). State of the art electrical discharge machining (EDM), International Journal of Machine Tools and Manufacture, Vol. 43, No. 13, 1287-1300, doi: 10.1016/S0890-6955(03)00162-7.

[5] Shrivastava, P.K., Dubey, A.K. (2014). Electrical discharge machining-based hybrid machining processes: A review, Proceedings of the Institution of Mechanical Engineers, Part B: Journal of Engineering Manufacture,Vol. 228, No. 6, 799-825, doi: 10.1177/0954405413508939. 
[6] Arrazola, P.-J., Garay, A., Iriarte, L.-M., Armendia, M., Marya, S., Le Maître, F. (2009). Machinability of titanium alloys (Ti6Al4V and Ti555.3), Journal of Materials Processing Technology, Vol. 209, No. 5, 2223-2230, doi: 10.1016/j.jmatprotec.2008.06.020.

[7] Abu Qudeiri, J.E., Mourad, A.-H.I., Ziout, A., Abidi, M.H., Elkaseer, A. (2018). Electric discharge machining of titanium and its alloys: Review, The International Journal of Advanced Manufacturing Technology, Vol. 96, 1319-1339, doi: 10.1007/s00170-018-1574-0.

[8] Kumar, S., Singh, R., Batish, A., Singh, T.P. (2012). Electric discharge machining of titanium and its alloys: A review, International Journal of Machining and Machinability of Materials, Vol. 11, No. 1, 84-111, doi: 10.1504/ IJMMM.2012.044922.

[9] Muthuramalingam, T., Mohan, B. (2015). A review on influence of electrical process parameters in EDM process, Archives of Civil and Mechanical Engineering, Vol. 15, No. 1, 87-94, doi: 10.1016/i.acme.2014.02.009.

[10] Krishna Mohana Rao, G., Rangajanardhaa, G., Hanumantha Rao, D., Sreenivasa Rao, M. (2009). Development of hybrid model and optimization of surface roughness in electric discharge machining using artificial neural networks and genetic algorithm, Journal of Materials Processing Technology, Vol. 209, No. 3, 1512-1520, doi: 10.1016/i.jmatprotec.2008.04.003.

[11] Keskin, Y., Halkacl, H.S., Kizil, M. (2006). An experimental study for determination of the effects of machining parameters on surface roughness in electrical discharge machining (EDM), The International Journal of Advanced Manufacturing Technology, Vol. 28, 1118-1121, doi: 10.1007/s00170-004-2478-8.

[12] Salonitis, K., Stournaras, A., Stavropoulos, P., Chryssolouris, G. (2009). Thermal modeling of the material removal rate and surface roughness for die-sinking EDM, The International Journal of Advanced Manufacturing Technology, Vol. 40, 316-323, doi: 10.1007/s00170-007-1327-y.

[13] Kumar, A., Kumar, V., Kumar, J. (2013). Investigation of machining parameters and surface integrity in wire electric discharge machining of pure titanium, Proceedings of the Institution of Mechanical Engineers, Part B: Journal of Engineering Manufacture, Vol. 227, No. 7, 972-992, doi: 10.1177/0954405413479791.

[14] Myers, R.H., Montgomery, D.C., Anderson-Cook, C.M. (2016). Response surface methodology: Process and product optimization using designed experiments, $4^{\text {th }}$ Edition, John Wiley \& Sons, New Jersey, USA.

[15] Makadia, A.J., Nanavati, J.I. (2013). Optimisation of machining parameters for turning operations based on response surface methodology, Measurement, Vol. 46, No. 4, 1521-1529, doi: 10.1016/i.measurement.2012.11.026.

[16] Behera, S.K., Meena, H., Chakraborty, S., Meikap, B.C. (2018). Application of response surface methodology (RSM) for optimization of leaching parameters for ash reduction from low-grade coal, International Journal of Mining Science and Technology, Vol. 28, No. 4, 621-629, doi: 10.1016/i.ijmst.2018.04.014.

[17] Shandilya, P., Jain, P.K., Jain, N.K. (2012). Parametric optimization during wire electrical discharge machining using response surface methodology, Procedia Engineering, Vol. 38, 2371-2377, doi: 10.1016/j.proeng.2012. $\underline{06.283}$.

[18] Bhowmik, S., Jagadish, Gupta, K. (2019). Modeling and optimization of advanced manufacturing processes, Springer International Publishing, Cham, Switzerland, doi: 10.1007/978-3-030-00036-3.

[19] Baş, D., Boyacı, İ.H. (2007). Modeling and optimization I: Usability of response surface methodology, Journal of Food Engineering, Vol. 78, No. 3, 836-845, doi: 10.1016/j.jfoodeng.2005.11.024.

[20] Casalino, G., Facchini, F., Mortello, M., Mummolo, G. (2016). ANN modelling to optimize manufacturing processes: The case of laser welding, IFAC-PapersOnLine, Vol. 49, No. 12, 378-383, doi: 10.1016/j.ifacol.2016.07.634.

[21] Paliwal, M., Kumar, U.A. (2009). Neural networks and statistical techniques: A review of applications, Expert Systems with Applications, Vol. 36, No. 1, 2-17, doi: 10.1016/j.eswa.2007.10.005.

[22] Ranganathan, S., Senthilvelan, T., Sriram, G. (2010). Evaluation of machining parameters of hot turning of stainless steel (Type 316) by applying ANN and RSM, Materials and Manufacturing Processes, Vol. 25, No. 10, 11311141, doi: $10.1080 / 10426914.2010 .489790$.

[23] Çaydaş, U., Hasçalık, A., Ekici, S. (2009). An adaptive neuro-fuzzy inference system (ANFIS) model for wire-EDM, Expert Systems with Applications, Vol. 36, No. 3, Part 2, 6135-6139, doi: 10.1016/j.eswa.2008.07.019.

[24] Buragohain, M. (2009). Adaptive network based fuzzy inference system (ANFIS) as a tool for system identification with special emphasis on training data minimization, Doctoral dissertation, Indian Institute of Technology Guwahati, Assam, India, from http://gyan.iitg.ernet.in/handle/123456789/256, accessed October 27, 2020.

[25] Karaboga, D., Kaya, E. (2016). An adaptive and hybrid artificial bee colony algorithm (aABC) for ANFIS training, Applied Soft Computing, Vol. 49, 423-436, doi: 10.1016/j.asoc.2016.07.039.

[26] Karaboga, D., Kaya, E. (2019). Adaptive network based fuzzy inference system (ANFIS) training approaches: A comprehensive survey, Artificial Intelligence Review, Vol. 52, 2263-2293, doi: 10.1007/s10462-017-9610-2.

[27] Chandrasekaran, M., Muralidhar, M., Krishna, C.M., Dixit, U.S. (2010). Application of soft computing techniques in machining performance prediction and optimization: A literature review, The International Journal of Advanced Manufacturing Technology, Vol. 46, 445-464, doi: 10.1007/s00170-009-2104-X.

[28] Yilmaz, I., Kaynar, O. (2011). Multiple regression, ANN (RBF, MLP) and ANFIS models for prediction of swell potential of clayey soils, Expert Systems with Applications, Vol. 38, No. 5, 5958-5966, doi: 10.1016/i.eswa.2010. $\underline{11.027}$.

[29] Mukherjee, I., Ray, P.K. (2006). A review of optimization techniques in metal cutting processes, Computers \& Industrial Engineering, Vol. 50, No. 1-2, 15-34, doi: 10.1016/i.cie.2005.10.001.

[30] Yang, X.S. (2013). 1 - Optimization and metaheuristic algorithms in engineering, Metaheuristics in Water, Geotechnical and Transport Engineering, 1-23. doi: 10.1016/B978-0-12-398296-4.00001-5.

[31] Beheshti, Z., Shamsuddin, S.M.H. (2013). A review of population-based meta-heuristic algorithm, International Journal of Advances in Soft Computing and Its Applications, Vol. 5, No. 1, 1-35. 
[32] Klancnik, S., Hrelja, M., Balic, J., Brezocnik, M. (2016). Multi-objective optimization of the turning process using a Gravitational Search Algorithm (GSA) and NSGA-II approach, Advances in Production Engineering \& Management, Vol. 11, No. 4, 366-376, doi: 10.14743/apem2016.4.234.

[33] Rao, R.V. (2016). Jaya: A simple and new optimization algorithm for solving constrained and unconstrained optimization problems, International Journal of Industrial Engineering Computations, Vol. 7, 19-34, doi: $10.5267 /$ j.ijiec.2015.8.004.

[34] Agarwal, N., Shrivastava, N., Pradhan, M.K. (2020). Optimization of relative wear ratio during EDM of titanium alloy using advanced techniques, SN Applied Sciences, Vol. 2, Article No. 99, doi: 10.1007/s42452-019-1877-2.

[35] Rao, R.V., Rai, D.P., Ramkumar, J., Balic, J. (2016). A new multi-objective Jaya algorithm for optimization of modern machining processes, Advances in Production Engineering \& Management, Vol. 11, No. 4, 271-286, doi: 10.14743/apem2016.4.226.

[36] Singh, M., Ramkumar, J., Rao, R.V., Balic, J. (2019). Experimental investigation and multi-objective optimization of micro-wire electrical discharge machining of a titanium alloy using Jaya algorithm, Advances in Production Engineering \& Management, Vol. 14, No. 2, 251-263, doi: 10.14743/apem2019.2.326.

[37] Al-Refaie, A., Lepkova, N., Abbasi, G., Bani Domi, G. (2020). Optimization of process performance by multiple pentagon fuzzy responses: Case studies of wire-electrical discharge machining and sputtering process, Advances in Production Engineering \& Management, Vol. 15, No. 3, 307-317, doi: 10.14743/apem2020.3.367.

[38] Payal, H., Bharti, P.S., Maheshwari, S., Agarwal, D. (2020). Machining characteristics and parametric optimisation of Inconel 825 during electric discharge machining, Tehnički Vjesnik - Technical Gazette, Vol. 27, No. 3, 761-772, doi: $10.17559 /$ TV-20190214135509.

[39] Daneshmand, S., Neyestanak, A.A.L., Monfared, V. (2016). Modelling and investigating the effect of input parameters on surface roughness in electrical discharge machining of CK45, Tehnički Vjesnik - Technical Gazette, Vol. 23, No. 3, 725-730, doi: 10.17559/TV-20141024224809.

[40] Rao, R.V. (2020). Rao algorithms: Three metaphor-less simple algorithms for solving optimization problems, International Journal of Industrial Engineering Computations, Vol. 11, 107-130, doi: 10.5267/j.ijiec.2019.6.002.

[41] Rao, R.V., Kalyankar, V.D. (2014). Optimization of modern machining processes using advanced optimization techniques: A review, The International Journal of Advanced Manufacturing Technology, Vol. 73, 1159-1188, doi: 10.1007/s00170-014-5894-4.

[42] Liu, P., Leng, W., Fang, W. (2013). Training ANFIS model with an improved quantum-behaved particle swarm optimization algorithm, Mathematical Problems in Engineering, Vol. 2013, Article ID 595639, doi: 10.1155/ 2013/595639.

[43] Singh, N.K., Singh, Y., Kumar, S., Upadhyay, R. (2020). Integration of GA and neuro-fuzzy approaches for the predictive analysis of gas-assisted EDM responses, SN Applied Sciences, Vol. 2, Article No. 137, doi: 10.1007/s42452019-1533-x. 
APEM
Advances in Production Engineering \& Management Letnik 16 | Številka 2 | Junij 2021 | Strani 145-160 https://doi.org/10.14743/apem2021.2.390
ISSN 1854-6250

Spletna stran: apem-journal.org Izvirni znanstveni članek

\title{
Hibridni algoritem ANFIS-Rao za modeliranje in optimizacijo površinske hrapavosti pri elektroerozijski obdelavi
}

\author{
Agarwal, N. ${ }^{a}{ }^{,}$, Shrivastava, N. ${ }^{a}$, Pradhan, M.K. ${ }^{b}$ \\ aDepartment of Mechanical Engineering, UIT, Rajiv Gandhi Proudyogiki Vishwavidyalaya, Bhopal, India \\ bDepartment of Mechanical Engineering, Maulana Azad National Institute of Technology, Bhopal, India
}

\section{POVZETEK}

Napredne tehnike modeliranja in optimizacije so danes nujne za učinkovito uporabo kompleksnih obdelovalnih procesov, kot je obdelava z elektroerozijo (EDM). Za ovrednotenje enega od pomembnih parametrov celovitosti površinske integritete (SI), tj. površinske hrapavosti $R a$, je bila v tej raziskavi titanova zlitina strojno obdelana $\mathrm{z}$ uporabo različnih električnih vhodnih parametrov. Metodologija odzivne površine (RSM) je bila uporabljena za načrtovanje eksperimenta in za ustvarjanje učne baze podatkov. S pridobljenim naborom podatkov za učenje je bil razvit in optimiziran model umetne nevronske mreže (ANN) za $R a$. Dodatno je bil za $R a$ razvit tudi model s prilagodljivimi nevronskimi mrežami z mehkim identifikacijskim sistemom (ANFIS). Optimizacija razvitega modela ANFIS je bila narejena z uporabo najnovejših optimizacijskih tehnik: Rao algoritma in Jaya algoritma. Različni statistični parametri, kot so povprečna kvadratna napaka (MSE), srednja absolutna napaka (MAE), koren povprečne kvadratne napake (RMSE), povprečna napaka pristranskosti (MBE) in povprečna absolutna odstotna napaka (MAPE) pokažejo, da je ANFIS model boljši od modela ANN. Oba optimizacijska algoritma omogočita znatno izboljšanje površinske integritete strojno obdelane površine. Pri primerjavi algoritma Rao in algoritma Jaya za optimizacijo je bilo ugotovljeno, da algoritem Rao deluje bolje kot algoritem Jaya.

\author{
PODATKI O ČLANKU \\ Ključne besede: \\ Obdelava z elektroerozijo (EDM); \\ Titanova zlitina; \\ Hrapavost površine; \\ Modeliranje; \\ Optimizacija; \\ Umetne nevronske mreže (ANN); \\ Prilagodljive nevronske mreže $\mathrm{z}$ \\ mehkim identifikacijskim siste- \\ mom (ANFIS); \\ Rao algoritem; \\ Jaya algoritem
}

*Kontaktna oseba:

neeraj.bhopal@gmail.com

(Agarwal, N.)

Zgodovina članka:

Prejet 27. oktobra 2020

Popravljen 14. marca 2021

Sprejet 15. maja 2021

\section{(i)}

Content from this work may be used under the terms of the Creative Commons Attribution 4.0 International the Creative Coms wons . Any further distributionational must (CC BY 4 ). Any fun the must maintain attribution to the author(s) and the title of
the work, journal citation and DOI. 